Institute of Economic Studies, Faculty of Social Sciences Charles University in Prague

\title{
Markets vs. Politics Correcting Erroneous Beliefs Differently
}

\section{Martin Gregor}




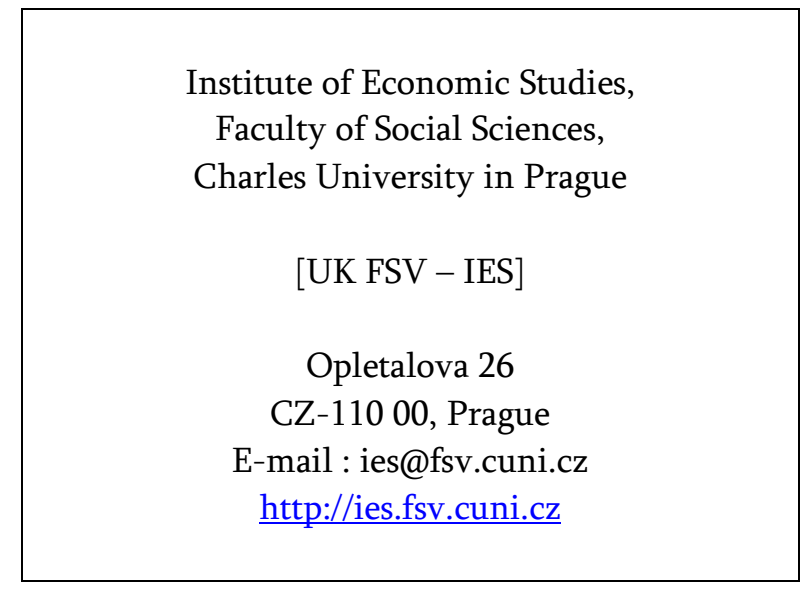

\begin{tabular}{|c|}
\hline $\begin{array}{c}\text { Institut ekonomických studií } \\
\text { Fakulta sociálních věd } \\
\text { Univerzita Karlova v Praze }\end{array}$ \\
Opletalova 26 \\
$11000 \quad$ Praha 1 \\
$\begin{array}{c}\text { E-mail : ies@fsv.cuni.cz } \\
\text { http://ies.fsv.cuni.cz }\end{array}$ \\
\hline
\end{tabular}

Disclaimer: The IES Working Papers is an online paper series for works by the faculty and students of the Institute of Economic Studies, Faculty of Social Sciences, Charles University in Prague, Czech Republic. The papers are peer reviewed, but they are not edited or formatted by the editors. The views expressed in documents served by this site do not reflect the views of the IES or any other Charles University Department. They are the sole property of the respective authors. Additional info at: ies@fsv.cuni.cz

Copyright Notice: Although all documents published by the IES are provided without charge, they are licensed for personal, academic or educational use. All rights are reserved by the authors.

Citations: All references to documents served by this site must be appropriately cited.

\section{Bibliographic information:}

Gregor, M. (2007). “Markets vs. Politics, Correcting Erroneous Beliefs Differently. ” IES Working Paper 21/2007. IES FSV. Charles University.

This paper can be downloaded at: http://ies.fsv.cuni.cz 


\title{
Markets vs. Politics Correcting Erroneous Beliefs Differently
}

\author{
Martin Gregor" \\ \# Institute of Economic Studies, Charles University, Prague \\ Opletalova 26, CZ-110 00, Prague \\ E-mail: gregor@fsv.cuni.cz
}

June 2007

\begin{abstract}
:
In the fields of social choice, public choice and political economics, the main difference between private and political choice is whether individual preferences are aggregated to make a decision. A much less studied difference is whether beliefs are aggregated to make a decision. In this paper, we argue that the need for aggregation creates different incentives for belief updates in private and political choice. We review contemporary theories of biased beliefs in politics: Bayesian misperceptions, behavioral anomalies, and rational irrationality. We examine assumptions and consequences of all the approaches vis-à-vis issues of common knowledge, stability, symmetry, and multiplicity of stable states. As a route for further analysis, we construct an evolutionary model including a coordination failure. Differences in learning dynamics make the political play of this baseline game Pareto-inferior to the private play.
\end{abstract}

Keywords: public choice, political economics, beliefs, learning

JEL: B53, D72, D83.

\section{Acknowledgements:}

Roger Koppl and Mark Skousen deserve thanks for valuable comments to a very preliminary version of the paper. Support provided from GAUK 319/2006/AEK/FSV is gratefully acknowledged. 


\section{Introduction}

In public choice and political economics, disagreement or conflict is traditionally attributed to heterogeneity of values, interests, or goals (Persson and Tabellini, 2000). By assuming conflicting objectives, one gets around heterogeneity in beliefs on how the economic world actually works, and political phenomena are explained without any reference to errors on the part of policy-makers or voters. Motivation for this abstraction is expressed relentlessly in Wittman (1989, p. 1421): he rejects to explain government failures by just 'extreme voter stupidity'. A typical example of this approach is incorporation of rational expectations into the political business cycle, whereby Alesina and Roubini (1995) eliminated myopia of voters.

Whether this modeling strategy is necessary and sufficient to address the key issues of political economy remains nevertheless an open question. Specifically regarding political business cycles with rational expectations, Blankart and Koser (2006, p. 179) claim that they 'remain in competition with the alternative and (at least sometimes) empirically betterperforming models of public choice'. More generally, in some contexts one finds it puzzling that political economy models do not involve any error or mistake, and that players manage to converge on equilibria with sophisticated beliefs and strategies. To completely disregard that false descriptive beliefs exist and are corrected over the course of the play then restricts attention to epiphenomena or leads to certain dubious implications. For instance, models of the communist economy where apparatchiks possess with the same knowledge on the role of price system as $\mathrm{PhD}$ economists have (e.g. Shleifer and Vishny, 1992), appear implausible to anyone with more profound experience from the former Communist bloc.

An alternative viewpoint is that false descriptive beliefs persist and significantly affect policy outcomes, even in the long term. What is even more important, incentives to correct erroneous beliefs in markets may differ from incentives in politics. Traditionally, this problem is understood under the rubric of rational ignorance, where information gathering in politics is suboptimal due to uncompensated positive externalities of informed voting; however, latest advances show that this explanation is unsatisfactory, for voters can easily get reliable estimates at very low costs (Martinelli 2005). Alternative explanations on the role of false beliefs in politics are proposed and examined.

Many prominent economists from different ages have elaborated on the idea that in politics people have erroneous beliefs, e.g. James Stuart Mill (Mill, 1861/1972), Ludwig von Mises (Mises, 1949), and James Buchanan (Buchanan and Wagner, 1977). It is no coincidence that the role of false descriptive beliefs on economic policy is approached as a crucial issue in schools or traditions which attempt to derive general conclusions on the role of the 
government intervention in the economy. Particularly illustrating is the difference between Chicago and Austrian schools of economics, discussed at length in Skousen (2005). Chicago economics leans to the explanation that any market, even political one, sufficiently clears. This is spelled out in the idea of efficient democratic political markets, suggested initially in Stigler (1971) and reinvigorated in Wittman (1995). In the latter book, labeled as an 'amazing hit' of Chicago school of political economy (Caplan 2005a), Wittman argues that democratic political markets are efficient, because: a) voters are rational, b) compensations drive redistributive politics to the centrist position, and c) adjustments between political supply and demand is instantaneous or take place without impediments. There is no significant difference between correction of beliefs and strategies in markets and in politics.

Austrian economists have a distinctly different approach. Firstly, Austrians argue that ideas, ideologies or beliefs are important and exogenous determinants in the decision-making. According to Mises, '[e]verything that happens in the social world in our time is the result of ideas.' (Mises 1979, p. 108) Human action, by reflecting preferences, reflects also ideological and descriptive beliefs. Secondly, the market with political ideas not necessarily features the best ideas available. Ideas are aggregate sets of descriptive beliefs which evolve and are tested; the tests are not only by empirical observation (benchmarking and comparing ex ante vs. ex post outcomes), but also by manipulation, indoctrination, and via the media. Biases are sustainable for a very long time, which Austrians casually explain by referring to the history of political ideas. If there is convergence towards elimination of proponents of biases, it is very slow and hard to track; the communist empire with nowadays apparently mistaken ideology lasted over 70 years, yet numerous proponents of the communist ideology kept their support till the very end.

The perspective held by Austrians and others on the systematically erroneous beliefs has been recently resurrected because of advances in public choice and political economics. In turn, these recent developments reinvigorated attempts to link classic Austrian insights to contemporary research on political economies, like in Caplan and Stringham (2005). Three major motivations for revived interest in political learning can be identified, evidence on maintaining (erroneous) political beliefs by laymen, models of ideological or principled candidates replacing opportunistic candidates, and the lack of a comprehensive theory of reform resistance. A unified framework on market and political updates of false beliefs is nevertheless far away from our reach.

This paper proceeds as follows. In Section 2, we highlight recent evidence on systematic biases in policy-relevant beliefs and elaborate on the aforementioned motivation. The section also introduces the reader to core issues related to modeling political learning. Next, we review recent theories of imperfect learning in politics: Bayesian misperceptions in Section 3, behavioral anomalies (especially confirmatory bias) in Section 4, and rational irrationality in Section 5. We examine assumptions and implications of all the approaches. We analyze whether they explain if incentives to correct beliefs in politics are weaker than incentives to improve beliefs on markets. In Section 6, we construct an evolutionary model with a coordination failure. We prove that due to different belief updates, the collective play of this baseline game is never Pareto-superior to the private play. In final Section 7, we conclude by arguing that original insights of Austrians are useful part of this research, but have to be transformed into formalized models with adaptive learning and evolutionary dynamics. 


\section{Preliminaries}

\subsection{Motivation}

Anecdotic evidence from sciences and history reads that people not only repeat wrong decisions, but also keep false descriptive beliefs for a long time. In terms of politics and specifically economic policy, a host of studies recognized systematic differences of beliefs between laymen and experts; voters underestimate the economic benefits of free trade, overestimate the percentage of the budget spent on welfare, and misinterpret low economic growth as absolute economic decline (Caplan 2001b, 2002; National Survey of Public Knowledge of Welfare Reform and the Federal Budget 1995; Survey of Americans and Economists on the Economy 1996). Rubin (2003) identifies 'folk economics' as economics of wealth allocation, not production. Quoting surveys on popular beliefs, experimental economics on exchange, monitoring, and shirking, and studies on how children learn economics, Rubin finds that folk economics largely disregards phenomena of specialization, division of labor, capital investment, or economic growth.

Closely related is the literature on determinants of descriptive beliefs, especially ideological ones. In a trading experiment where subjects assessed to what extent price will reflect supply and demand, Austin and Cox (2007) illustrate that ideological differences influence descriptive beliefs about economic institutions. Blinder and Krueger (2004) also find that economic knowledge is determined by ideology, not the use of information. They obtain evidence for idealism (or sociotropic motivation), namely when it comes to national economic policy, people are often more interested in what they perceive to be the common good than they are in their own narrow self-interest.

Public choice and political economics have undergone a related development in the revival of interest in partisan (ideological or principled) candidates, instead of opportunistic candidates (Besley 2006). Beliefs of politicians have a role, for which evidence can be drawn from quasiexperiments with lack of policy convergence after a common popularity shock (Lee et al. 2004). Certainly, this complex issue is affected by the origin and functioning of parties, but the inability of candidates to commit to a policy concessions implies that they or their organizations indeed follow stable objectives, and possess with arguably stable (and not necessarily homogenous) descriptive beliefs.

In addition, public choice and political economics still provides inconclusive explanations on transaction costs of reforms of the public sector, sufficient to explain delays and political deadlocks. For economists, it is notoriously difficult to explain why there is such a striking

difference between outcomes of current political markets and policy recommendations, if efficiency-enhancing measures can be complemented with compensatory mechanisms. Established political-economy explanations resort to very specific assumptions. Alesina and Drazen (1991) presume a non-intuitive tax system with information asymmetry resulting in the production of costly signals, and receive a version of the war of attritions. Howitt and Windtrobe (1995) postulate that with any reform initiative, the issue fully discloses in public and the winner may be with some probability also the passive party which stayed behind. Uncertainty prevents from submitting a reform initiative. The model however requires passive media and voters, impossibility to bargain as well as a particular distribution of preferences. That reform resistance can be associated simply with ignorance has been tested in Heinemann (2004). His working hypothesis is that there should be a negative function of the population's level of economic education. Unfortunately, there is no internationally consistent data set on economic education, so he uses variables describing the general state of education such as school enrolment ratios, the availability of media information, and the development of the 
financial sector such as credit aggregates. He gets a significant effect of these variables upon the reform realization, hence tentative evidence on the importance of the lack of knowledge in policy-making.

\subsection{Modeling}

Several frameworks capture the intuition that homo economicus may learn differently than homo politicus. We investigate in details hypotheses of Bayesian learning from biased signals (misconceptions), behavioral anomalies, especially confirmatory bias or overconfidence, and meta-rational irrationality. Before proceeding to each theory, we recognize a couple of issues that any theory of learning, Bayesian or non-Bayesian, has to address.

a) Deviation from the best response. Does inability to derive a correct belief necessarily imply deviation from the best response strategy? If there is a deviation, the incorrect beliefs are not serving one's own interests and deserve to be called false consciousness (Bodreaux 2003). The problem is that strong evolutionary pressure will be exerted on corrections towards the best response, with associated updates in beliefs; one has to explain why deviation towards the best response, e.g. via random experimentation, is impossible or costly.

b) The best response with the false beliefs. We may have a case when the beliefs are selfserving rationalizations of material interests ('where you stand depends on where you sit') and are upheld since an update toward a more correct belief could lead to a deviation from the best response. This explanation is plausible, but needs very detailed assumptions on the underlying game where this 'equilibrium with illusions' occurs. One attempt is coordination failure in Section 6. Empirically, this poses a problem for regressions that attempt to explain descriptive beliefs via ideology; the positive relationship between beliefs and ideology is spurious. Austin and Cox (2007) claim that their results are inconsistent with the idea that ideology and belief are mere self-serving rationalizations of interest. Yet, they also think that over shorter time periods, ideology is a relatively stable and exogenous determinant of descriptive beliefs about the workings of the economic world.

c) Symmetry on the supply versus demand side. If people are prone to have false descriptive beliefs, the biases must be present both on the supply and demand side. This is, among others, a problem for confirmatory bias applied in the principal-agent framework. It also poses a challenge for self-selection into supply under heterogeneous beliefs.

d) If information is acquired up to the point where the marginal cost equals the marginal benefit (Stigler 1971), there is no rationale to assume zero cost of information on the benefits and costs of acquiring the information. Unless one purchases or seeks information on the basis of correct priors on the cost and benefits of the search, we have for any item of practical information an infinite number of benefit and cost schedules: the cost of acquiring the practical information, the cost of information on the cost of the information, and so on.

e) Common knowledge. If possibility of an erroneous belief is common knowledge, we need to know what gives credibility to the statements; otherwise, massive cheap talk occurs. For example, if receivers believe that ideology partly reflects interests, then the question of what to believe depends less on the receiver's ideology than it does on the receiver's perception of the difference between his or her own ideology and that of the sender. If something is not common knowledge, we run into the danger of arbitrary modeling. Recall also an important consequence of Bayesian learning, namely that people cannot 
'agree to disagree': if all important aspects are common knowledge, exchange of opinions and common priors must lead to agreement (Aumann, 1976).

f) Multiple stable states. Technically speaking, it is not so difficult to create a model with coordination failure where a population converges to an inefficient stable state in pure strategies. A far more complicated is to get a situation where the population is mixed and stable, i.e. only a part of population holds false beliefs and for endogenous, not exogenous reason. There must be either a very special dynamics or those with good beliefs must have some benefit from individuals having false beliefs and vice versa.

g) Comparative statics. Does the model imply that if an error gets costlier, the size of error declines? This is in general a message of simple heuristics approach (Gigenrenzer et al. 1999), expressive voting (Brennan and Hamlin 1998) as well as rational irrationality (Caplan 2001). Cowen (2005) however claims that for pride goods, this relationship need not hold.

\section{Bayesian learning}

Even if individuals create rational expectations, Romer (2003) posits that the mean belief in a large population is biased whenever errors in individual beliefs are correlated. This idea is modeled in a setup with two policies. Identical voters have priors on their relative advantage. At a known cost, they can get a signal on the relative advantage and can also observe signals of other voters. Each individual selects the number of her costly observations. The problem for inference is that the signal consists of true value and two types of errors - common and idiosyncratic. The common part is identical to all voters (hence is correlated), whereas the idiosyncratic part is specific for each individual. This means that an individual observing signals can go around the idiosyncratic part, but not the common part.

The shortcomings of this approach are as follows:

a) Distribution of signals can be obtained only at a cost. This requires careful interpretation of the cost of the observing the distribution signals. In politics, opinion polls (and summaries of expert judgments) are virtually costless, hence even an individual who doesn't observe any signal (e.g., doesn't watch TV) should be able to get the aggregate information. This echoes recent theories on the collective aggregation of information, where the electorate with rational ignorance may have asymptotically perfect knowledge (Martinelli 2005).

b) Common part of error. If the signal realizes with a political debate, or a political event, the common part of error can be explained by argumentation skills, spin, popularity or attractiveness of one candidate over another. This is fully in spirit of probabilistic voting literature. However, it is unlikely that such signals are randomly drawn from distributions independent over time; for instance, popularity shocks are persistent over time.

c) Discounting bias. If variance of the common error is low comparing with variance of the idiosyncratic error, than people make almost unbiased estimates even with costless priors. Other than zero expected value is not a complication either: if individuals know that, for example, Candidate A is always much nicer than Candidate B, they would discount attractiveness of his or her talk. This is similar to Austen-Smith (1991) who claims that under asymmetric information on impact of transfers and tax incidence, voters insure by buying less transfers and lower taxes; only those programs that credibly signal their merit will win approval. That the improved information on common error is individually specific and cannot be transmitted contrasts with the probabilistic-voting literature (Persson and Tabellini 2000), where a popularity shock realizes only once, and demand 
side cannot tackle it; its anticipated effect is mitigated rather by the supply side, i.e. the competition of politicians.

d) Individual decision on acquiring signal. The number of signals acquired is independent on the values of the acquired data. Romer (2003) assumes individual-specific benefit and cost functions from acquiring information, solely motivated by civic engagement or expressive motives. This goes against Stigler (1971), where acquiring information depends on the expected benefit of the correction. Although this can be handled formally (distributions of both common and idiosyncratic parts are known, so an individual can compute expected improvement of obtaining a signal in the next period), the problem is that we may get a very complicated dynamics of adjustments, depending on the realization of shocks in different periods.

e) Application to private choice. Superiority of private over public choice could be related to the fact that prior private consumption, one can observe consumption of the good by others. With exception of yardstick competition, that is in politics impossible. Unfortunately not much is to be inferred from this result, since the superiority is related to assumption that political choice involves no sequential consumption; by introducing sequential private choice, we create extra opportunities for obtaining true information, which makes comparison of politics and markets meaningless as timing differs. What would happen for identical timing-when both the political and private choices were sequential-is not unambiguous; in this model, there would probably be no differences. In other words, this type of correlated error seems not to be helpful in addressing the difference between market learning and political learning.

\section{Behavioral anomalies}

\subsection{Innate biases}

Evolutionary psychology suggests that the explanation of a large number of biases lies in persistent traits of human psyche, and that systematically wrong descriptive beliefs can be related to behavioral traits gained in the very past. Rubin (2003) refers to anthropological division of civilization into mobile and sedentary societies; the former being egalitarian, based on hunter-gatherers, with little food storage, little division of labor, and occupational specialization given only by age. As a result, 'instinctive economics' disregards capital investments and division of labor. This simple but ambitious explanation is very difficult to challenge since economic education that aims to deprive people of folk or instinctive economics is not very well measured, and also because descriptive beliefs depend on ideology, which is exogenous in the short term, but arguably endogenous in the long term (Austin and Cox, 2007).

\subsection{Status quo and loss aversion}

Heinemann (2004) argues that many psychological anomalies have a substantial explanatory potential particularly in the context of reform resistance. The status quo bias describes a situation where people have a preference for one option among many others only because this option happens to be the status quo. If a change occurs, this specific option loses attraction immediately. Loss aversion denotes the fact that the absolute change in utility associated with a loss is larger than the absolute change in utility associated with a gain. With loss aversion the utility function is non-continuous in the reference point which tends to be the status quo. All these anomalies work against reforms that change the status quo. 
The behavioral explanations nevertheless encounter severe problems if taken literally on markets with behaviorally unbiased partners. Specifically loss aversion combined with Sshaped utility curve would lead to the emergence of special version of insurance (Wittman 1995). Even if valid, they are of little use for our purpose because make no difference between private and collective choice. In addition, for any anomaly to exist, there is no need for biased descriptive beliefs; preferences are inconsistent with choice because of the psychologically predetermined structure of choice, not because of false beliefs.

\subsection{Confirmatory bias}

Confirmatory bias can be understood by a phrase that 'first impression matters', namely that one is overconfident about validity of an initially held hypothesis. Experiments and psychologists confirm that the way people search for, process, and remember information is guided by the priors (Camerer 1995). Rabin and Schrag (1999) were the first to model the confirmatory bias as overconfidence in the currently held hypothesis. Specifically, an agent initially believes that each of two possible states of the world is equally likely. The agent then receives a series of independent and identically distributed signals that are correlated with the true state. When the agent gets a signal that is counter to the hypothesis he currently believes is more likely, there is a positive probability that he misreads that signal as supporting his current hypothesis. Importantly, the agent is unaware that he is misreading evidence in this way and engages in Bayesian updating that would be fully rational given his environment provided he were not misreading evidence.

The problem with application of confirmatory bias in politics is arbitrariness of common knowledge. In Section V, Rabin and Schrag (1999) model principal-agent relationship when the principal is aware of agent's bias. Thereby they introduce a fundamental asymmetry in knowledge, because the principal is aware of the bias, but the agent is not. However, at least in citizen-candidate models, a politician must be behaviorally identical to the voter, hence asymmetry is unfounded. If both are unaware of any bias, we can have a very rich structure of updates ending in a pseudo-Bayesian equilibrium based on incorrect updates. If both are aware, then it depends on whether the bias is common knowledge - if so, then it is irrelevant for choice, since any agent can reconstruct her updates using the knowledge of the bias. Yet, if the bias is not common knowledge but is symmetric, then we again have a very specific problem of coordination on incorrect updates. In any case, either coordination is nearly by chance (nobody is aware of any bias), or coordination is an extremely deep informational problem involving many levels of knowledge (what the individual 1 thinks that the individual 2 thinks about what the individual 1 thinks about the individual 2 etc.). Simply, the lack of common knowledge makes the problem immensely complex. Indeed, even the authors honestly admit that 'usefully incorporating confirmatory bias into economic analysis will depend upon the extent to which people believe that others suffer from confirmatory bias' (Rabin and Schrag 1999, p. 71).

The most recent attempt to apply confirmatory bias into politics is Cowen (2005). He defines 'self-deception' as tendency to welcome confirming evidence for a prior but throw out disconfirming evidence. The problem is that he explains the phenomenon by two, mutually exclusive hypotheses. One is that 'the quest for pride causes individuals to throw away information that reflects badly on their values and their affiliation.' (Cowen 2005, p. 439) Values or affiliations are therefore consumption goods (pride goods), and one considers tradeoff between pride and material consumption. Another explanation is evolutionarily psychological. Self-deception is a second-best heuristics for individuals who need to boost motivation, command the loyalty of others, avoid depression, and protect themselves against a tendency towards distraction (Cowen 2005, p. 440). Nevertheless, none is, in fact, 
confirmatory bias or overconfidence as defined in the behavioral literature, e.g. Rabin and Schrag (2005).

At last, Cowen (2005) inclines to the pride-goods explanation of self-deception. The novelty is that any choice has both materially instrumental component and value (or emotional) component. This is exactly what expressive voting literature (Brennan \& Hamlin, 1998) captures under 'instrumental voting' (to affect what happens in the world) versus 'expressive voting' (to make a statement on values). This approach implies that efficiency is affected only if the consumption of pride goods produces externalities. Removal of self-deception is a classic collective action problem, identical information-gathering and incentives for rational ignorance. In this respect, it adds nothing extra to the concept of rational ignorance.

\section{Rational irrationality}

One of the most systematic and the most ambitious attempts to rationalize biased beliefs is 'rational irrationality' concept by Caplan (2000, 2001, 2003), related to the cognitive dissonance by Akerlof and Dickens (1982). An individual faces a trade-off between the amount of rationality and the amount of irrationality consumed. Rationality brings benefits in terms of identifying the best instruments to achieve personal goals, while irrationality delivers emotional benefits. Each individual has rational expectations on the costs and benefits of rationality, hence consumes a privately optimal amount of rationality.

Caplan (2001) argues that the opportunity costs of irrationality in market exceed opportunity costs of irrationality in politics, which he considers to be the key difference between the markets and politics. To illustrate different rationality in politics and private life, Caplan (2003, p. 221) uses the way people interpret autarky: "[T]he belief that protectionism is a wealth enhancing national policy makes little difference for the individual adherent, who still enjoys the benefits of international trade. But holding that household self-sufficiency is the path to prosperity has large private costs."

In other words, collective learning is less efficient than private learning due to positive externalities involved in improving an erroneous belief. Private costs of irrational bias in politics are negligible, so people tend to be biased, and politicians who win competition for the favor of voters with irrational biases tend to share those biases. This has interesting and profound implications not only for politics, but also for academic social criticism and other fields (Boudreaux and Crampton 2003).

One may speculate on the difference between imperfect rationality and imperfect information. Caplan (2003, p. 222) notes: 'Intuitively, a person with ample free information might still choose to irrationally disregard it; conversely, a person with virtually no information could still take full advantage of the little that he does know.' This suggests that the optimal level of rationality does not significantly change when media, interest groups and politicians bring virtually free information. If processing of information is too costly for a layman, additional items of information remain out of scope of his or her interest.

Certainly, the idea of rational irrationality can be falsified empirically, or rejected in theory. For the issue of laboratory tests, see discourse between Caplan (2005a, 2005b) and Wittman (2005a, 2005b); in this text, we focus exclusively on the theoretical part, and identify several caveats:

a) Why false beliefs as empirical shortcuts come into being? One explanation is via the cost of thinking. Strictly positive cost of thinking and more generally costs of investments into human capital are obvious. Caplan's intuition is however in the direction of pride goods mentioned in subsection 4.3. '[Y]ou may be willing to forego some wealth in order to 
retain cherished - though irrational - beliefs.' (Caplan 2003, p. 223) That invites an idea that changes in beliefs are avoided, because one pays special adjustment cost for leaving wrong beliefs and approximating true beliefs. To explain where this cost comes from, and why it is constant, needs very specific behavioral or evolutionarily psychological assumptions. Little is known on how these costs affect consumer behavior, and influence efficiency properties of market and political allocations.

b) Costless thinking on meta-level. Caplan divides rationality into two levels: metarationality, allocating rationality into activities, and rationality within the realm of each specific activity. As to the latter, we simply behave rationally only to extent chosen on the meta-level; we dispose with meta-rational expectations. If errors were due to lack of thinking, we could conjecture that on meta-level, thinking is costless, but on lower levels, thinking is costly. This asymmetry is problematic; why should one know the price of thinking, and not in the price of information, and vice versa. No justification for this asymmetry, or for any dualism of meta-level and normal levels, has been offered as yet.

c) Anyway, suppose we dispose with an unbiased estimate of costs of thinking. How could we arrive at the figure? It could be on the basis of the long-term experience. The psychic cost cannot be measured exactly before you start thinking, but can be approximated by the amount of time spent by thinking. An individual might summarize previous experiences into a vector of costs and a vector of benefits. A regression of non-linear costs on benefits might provide estimates of the benefit-cost parameters. If a rational individual had no reason to believe that the problem he is facing statistically significantly differs from the previous problems, he or she would use the predicted estimates for optimization. However, Caplan's idea is not that cognitive capacity is allocated, but that emotions are consumed.

d) Experience as a capital good. The allocation of rationality could be determined by a boundedly rational individual whose thinking on meta-level is costly. However, in such a model we implicitly introduce a dynamic setting without considering other factors. Experience (the result of thinking) might be a stock variable (human capital), and enters the decision-making process along with pure thinking. For such decision-making production, an individual gets an optimal amount of rationality when she optimizes evolution of capital over time, given the knowledge of depreciation rate, the expectation of dynamics of future problems, and the possible changes to her thinking costs. Now the problem becomes genuinely complex, and rational expectation assumption loses part of its appeal. The chance that a boundedly rational individual selects an optimal path of thinking investments turns to be very low.

e) Compensations for learning. A very unclear yet important issue is how opportunities to learn are evaluated and compensated. Consider the following problem exposed by Caplan (2003, p. 231): 'Suppose free trade provides $\$ 600$ in benefits to each voter, but $60 \%$ are willing to pay up to $\$ 2$ for the irrational belief that free trade costs them $\$ 1000$. A simple vote for free trade will clearly fail.' Ordinary logrolling, according to Caplan, cannot utilize forgone gains to trade, because agents still retain their false beliefs. Even if the minority of $40 \%$ gave all net benefits to the irrational majority (i.e. $\$ 400$ each), members of the irrational majority would consider that to be a loss of $\$ 600$ (\$1000-\$400), and would vote for protectionism (status quo). The obvious problem is that in such a case, voters are not rational on the meta-level. If they really had rational expectations, they would know that by investing $\$ 2$ of $\$ 400$ transfer into learning, they would realize net gain $\$ 398$. Another possibility is that the minority is able to condition the transfer on learning, which is a much more plausible option that to condition the transfer on vote with the secret ballot, as Caplan (2003) notes in fn. 11. 
f) Expertise and voters' activity. In certain areas, meta-rational individuals would behave as perfectly rational individuals. First of all, they would respond to credible signals of rationality or ability. If experts were able to produce credible (costly) signals of incurring thinking costs (such as having $\mathrm{PhD}$ in Economics), the meta-rational individuals would follow their advice, thereby economizing on thinking costs. But laymen don't follow experts views on many policy issues, which Caplan (2002) himself demonstrated in a survey comparing views of American economists and Americans on the economy.

g) Meta-rational individuals would be able to perfectly deduce that irrationality regarding specific issues is ruling the world. Any consequences related to the allocation of rationally would be known. For example, the meta-rational voters could not accuse political supply of inefficiency, for they could easily conjecture that the main problem lies in the undersupply of rational political demand due to collective action incentives. These strange consequences lead us astray from the meta-rational individuals.

\section{Political vs. individual adjustment}

The attempts to theorize on error in political economy among Austrian economists have to date led only to urgent claims to model learning and dynamics of the mixed economy at the micro- and macro-levels (Ikeda 2003). Evolutionary economics offers a toolkit, comprising ingredients such as strategies, populations of players, well-specified interactions, and fitness functions. Evolutionary reasoning can be divided into two branches, stability and dynamic concepts. For stability, we seek for stable states which cannot evolve, so mutants cannot outperform normal population. Such states frequently overlap with competitive equilibria in standard microeconomics, and with plausible refinements of Nash equilibria in game theory. For dynamic concepts, we have a colorful picture with differential equations and simulations.

Although externalities and collective action in an evolutionary framework often produce to interesting results, very little formal research has been conducted with regard to evolution on political markets where collective-action and the possibility to impose will upon the others problem are constantly present. An interesting example is Caveiro (2005) who applies neural networks to the adaptation of voters to political business cycle.

This section attempts to contribute to this literature and show that it may address modeling issues raised in Section 2.2. We introduce an evolutionary model of coordination of market exchanges in a heterogeneous population; the setup is a very straightforward application of elementary evolutionary game theory. The model identifies one way why political (centralized) decision-making is more likely to produce a coordination failure than individual (decentralized) decision-making. Unlike rational irrationality and other previously discussed explanations, the model abstracts from differences in marginal benefits from learning in private and collective choice. The thrust of the explanation lies exclusively in the different mechanics of adjustment of strategies on markets and in politics.

\subsection{Core assumptions}

The setup is simple: Two groups normalized to a unit-size, $A$ and $B$, differ in the mother tongues, $\alpha$ and $\beta$. In each of an infinite number of periods, a randomly selected pair $i \in A$ and $j \in B$ has an opportunity to trade, but the trade occurs only if both $i$ and $j$ can use the same language; gains from trade are 3 for each. Using the other language is costly, but let language $\alpha$ be simpler to master than $\beta$; the costs are 1 and 2 . These costs have to be expended in each and every period. As a result, trading in language $\alpha$ is Pareto-efficient, yielding in each period 
payoffs $(3,2)$, whereas trading in the more cumbersome language $\beta$ is less efficient, yielding payoffs $(1,3)$. Such a game is an asymmetric modification of Battle of Sexes.

The use of a native or foreign language can be organized individually or politically. By political choice, we mean that the majority elects in period $t=0$ a citizen-candidate who decides on the mandatory business language. Thereby we assume that by deciding that only native language is used, the politician can forbid members of her group to learn the other language privately. The native language is costless, but risky (trade may not happen), whereas the foreign language is risk-less, but costly. The two strategies can also be interpreted as a nationalistic versus cosmopolitan strategy (or stubbornness versus retreat). Payoffs in interactions between randomly drawn $i \in A$ and $j \in B$ are in Table 1.

Table 1: Payoff matrix

\begin{tabular}{|c|c|c|}
\hline$i \in A / j \in B$ & $\begin{array}{c}\text { Language } \alpha \\
\text { costly }\end{array}$ & $\begin{array}{c}\text { Language } \beta \\
\text { costless }\end{array}$ \\
\hline $\begin{array}{c}\text { Language } \alpha \\
\text { costless }\end{array}$ & 3,2 & 0,0 \\
\hline $\begin{array}{c}\text { Language } \beta \\
\text { costless }\end{array}$ & 1,2 & 1,3 \\
\hline
\end{tabular}

Each individual has a private belief that the trade partner is able or willing to speak the other language, $\sigma^{i}$ or $\sigma^{j}$. In order to work with a polymorphic interpretation of the population, we assume only pure beliefs, $\sigma^{i}, \sigma^{j} \in\{\alpha, \beta\}$. (Nevertheless, mixed beliefs can be incorporated by a straightforward extension, with only more complicated notation.) This gives us that the populations are represented by a realization of two binomial distributions $B^{A}(\cdot)$ and $B^{B}(\cdot)$ over $\{\alpha, \beta\}$, where we denote $a \equiv B^{A}(\alpha), 1-a=B^{A}(\beta), b \equiv B^{B}(\beta)$, and $1-b=B^{B}(\alpha)$. Hence, $a \in[0,1]$ denotes the share of group A that believes that members of group B are willing to use $\alpha$, and $b \in[0,1]$ is the share of group B that believes that members of group A are willing to use $\beta$. (In other than stable states, we add subscript $t$ denoting period $t$.) We will see anyone with belief $\sigma^{i}=\alpha$ or $\sigma^{j}=\beta$ plays only nationalistic strategy, so each variable also represents the share of those who are stubborn, namely are unwilling to pay the cost of using the other language.

\subsection{Individual adjustment}

For individual decision-making, each individual selects the language on the basis of her private belief, observes the payoffs and may update the belief, if incorrect. Then, the random draw of pairs $(i, j)$ is repeated. Since each individual has a pure belief and we have only strict best responses, one always plays a pure strategy, $\alpha$ or $\beta$ (e.g., $\sigma^{i}=\alpha$ implies strategy $\alpha$, and $\sigma^{j}=\beta$ implies strategy $\beta$ ). Therefore, one can check whether the belief about the trading partner was correct, or not, simply by observing her payoffs and the corresponding strategy profile.

By examination of Table 1, we can observe correct (equilibrium) beliefs in two strategy profiles (those with payoffs 3,2 and 1,3) and incorrect (out-of-equilibrium) beliefs in two 
strategy profiles (those with payoffs 0,0 and 1,2). What happens if the beliefs are incorrect? We have to specify the probability of adjustment of an individual strategy. Here, it is plausible to assume that the probability is linear in opportunity cost associated with the best response. In profile $[\alpha, \beta]$ with payoffs $(0,0)$, the opportunity costs are $1-0=1$ for player $i$ and $2-0=$ 2 for player $j$. (See Table 1.) This profile occurs with probability $a_{t} b_{t}$. In profile $[\beta, \alpha]$ with payoffs $(1,2)$, the opportunity costs are $3-1=2$ for player $i$ and $3-2=1$ for player $j$. This profile occurs with probability $\left(1-a_{t}\right)\left(1-b_{t}\right)$. Assuming probability of adjustment linear in opportunity cost with constant $0<p \leq 1$, we have two difference equations:

$$
\begin{gathered}
\dot{a}=2 p\left(1-a_{t}\right)\left(1-b_{t}\right)-p a_{t} b_{t}=p(1-a-b-a b) \\
\dot{b}=p\left(1-a_{t}\right)\left(1-b_{t}\right)-2 p a_{t} b_{t}=p(2-2 a-2 b+a b)
\end{gathered}
$$

The system converges to a stable state when $\dot{a}=\dot{b}=0$. This is equivalent to

$$
a+b+a b=1=a+b-a b / 2,
$$

which holds only if $a=0$ or $b=0$. By plugging into equation (3), we have two stable states, inefficient $(a, b)=(0,1)$ and efficient $(a, b)=(1,0)$. What is more interesting is to identify the basin of attraction for each stable state. This is difficult analytically, yet we can use Fig. 1 with arrows indicating the signs of attraction.

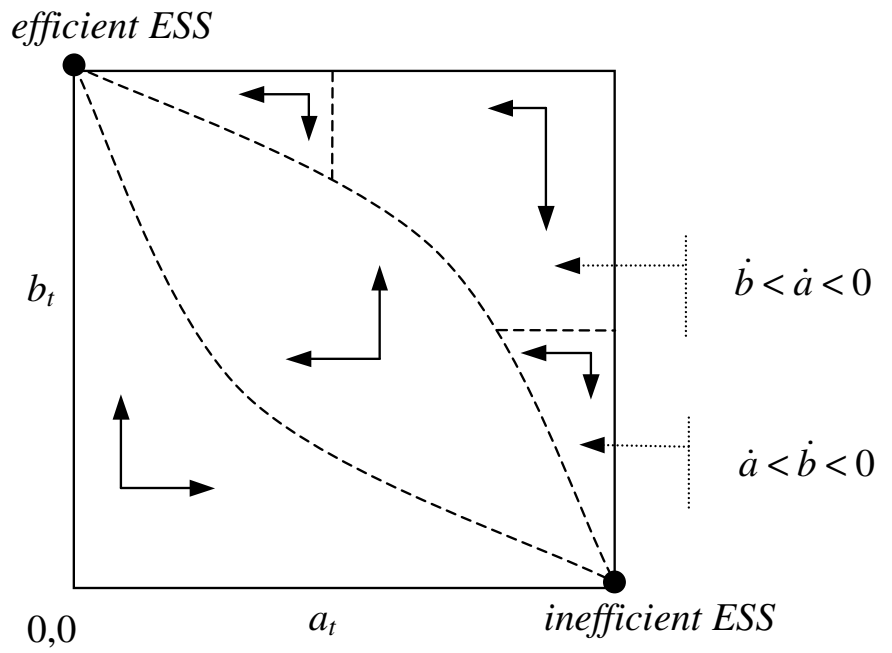

Fig. 1: Dynamics for individual adjustment 
Although we have two evolutionarily stable states (ESS), the basin of attraction for the inefficient one is a singleton. To see that, consider that on the neighborhood of the point, the only shares of population that are candidates for convergence lie in the upper right corner subset, $a>b$, where we have $\dot{a}<\dot{b}<0$. There is no trajectory that could start here and end up in the inefficient stable point, $(a, b)=(0,1)$. In other words, the adjustment dynamics described in equations (1) and (2) drives any population to the efficient stable state, with only one exception, if all start using language $\beta$, i.e. $\left(a_{0}, b_{0}\right)=(1,0)$.

\subsection{Political adjustment}

Suppose that two citizen candidates, each with a different belief, enter elections and manifest their beliefs. Voting is costless, and we concentrate on the equilibrium with sincere voting, namely when each individual votes for the language on the basis of her belief. This refinement is legitimate as long as individuals do not play weakly dominant strategies. Identity of the politicians depends on which type of private belief dominates in each group in period $t=0$.

In period $t=0$, each of elected citizen candidates adopts a mandatory language on the basis of his belief. Therefore, all trading pairs end up in an identical strategy profile. The profile is either an inefficient equilibrium, as in $[\beta, \beta]$ with payoffs $(1,3)$, or an efficient equilibrium, as in $[\alpha, \alpha]$ with payoffs $(3,2)$. There are two out-of-equilibrium profiles, $[\alpha, \beta]$ with payoffs $(0,0)$ and $[\beta, \alpha]$ with payoffs $(1,2)$. Table 2 summarizes.

Table 2: The strategy profile in political adjustment for $t=0$

\begin{tabular}{|c|c|c|}
\hline$a_{0}, b_{0}$ & $b_{0}<\frac{1}{2}$ & $b_{0} \geq \frac{1}{2}$ \\
\hline$a_{0} \geq \frac{1}{2}$ & $\begin{array}{c}\alpha, \alpha \\
\text { efficient }\end{array}$ & $\begin{array}{c}\alpha, \beta \\
\text { out of eq. }\end{array}$ \\
\hline$a_{0}<\frac{1}{2}$ & $\begin{array}{c}\beta, \alpha \\
\text { out of eq. }\end{array}$ & $\begin{array}{c}\beta, \beta \\
\text { inefficient }\end{array}$ \\
\hline
\end{tabular}

Equilibrium. If the profile is equilibrium, none of politicians has any incentive to change her belief. The citizens update beliefs like in individual choice. The only difference is that in individual adjustment, they could select a strategy corresponding to their beliefs, and thereby verify both belief and strategy; here, the strategy is mandatory, so they only verify the belief. Regardless of assumptions on the rate of adjustment, for $a_{0} \geq 1 / 2$ and $b_{0}<1 / 2$ (inefficient $[\beta, \beta]$ profile), we have $\dot{a} \geq 0$ and $\dot{b} \leq 0$. For $a_{0}<1 / 2$ and $b_{0} \geq 1 / 2$ (efficient $[\alpha, \alpha]$ profile), we have $\dot{a} \leq 0$ and $\dot{b} \geq 0$. Citizens' beliefs converge to the beliefs of the politicians, reflecting initial distribution $\left(a_{0}, b_{0}\right)$; any initial disagreement or heterogeneity in beliefs disappears throughout the process of political learning.

Out of equilibrium. Here, we have to determine how the politicians change their beliefs (and accordingly the mandatory language). We have at least two options, optimistic and realistic: i) they are able to coordinate on efficient, risk-dominant equilibrium, or ii) they adjust exactly like citizens until equilibrium is achieved. It also depends on the number of periods in- 
between consecutive elections. Regardless of these nuances, we will see that the main result, namely that political learning is less efficient than individual learning, preserves.

Start with profile $[\alpha, \beta]$ with payoff $(0,0)$, corresponding to $a_{0} \geq 1 / 2$ and $b_{0} \geq 1 / 2$. In case (i), when politicians immediately coordinate on the efficient equilibrium $[\alpha, \alpha]$, we have that player 2 retreats and learns $\alpha$. This implies adjustment $\dot{a} \geq 0$ and $\dot{b}<0$. If elections come early, we may have at the time of elections $b_{t}<1 / 2$ or $b_{t} \geq 1 / 2$. If $b_{t}<1 / 2, \alpha$-politicians are elected and we have an efficient equilibrium. Otherwise, we have again $[\alpha, \beta]$ profile, but since $b_{t}<b_{0}$, repeated elections are the same as convergence of citizens' beliefs under effective equilibrium.

In case (ii), when politicians adjust exactly like citizens, we have to specify the rate of adjustment. This should reflect opportunity costs. The opportunity cost for politician 1 is 1 , and the opportunity cost for politician 2 is 2 . Both opportunity costs are exerted with probability one. The dynamics is $\dot{a}=-p a_{t}$ and $\dot{b}=-2 p b_{t}$. It is again irrelevant whether elections arrive sooner or later because repeatedly elected politicians will only reflect adjustment of citizen beliefs that is identical as adjustment of politicians' beliefs.

Adjustment for profile $[\beta, \alpha]$ is analogous. Figure 2 illustrates the dynamics. For any initial distribution of beliefs, $\left(a_{0}, b_{0}\right)$, it shows which point is politically stable. If politicians out of equilibrium can coordinate on the risk-dominant equilibrium (which is the most optimistic), then we have an inefficient stable state for $\left(a_{0}, b_{0}\right) \in S_{0}$. If politicians adjust like citizens, then we have an inefficient stable state for $\left(a_{0}, b_{0}\right) \in S_{0} \cup S_{1} \cup S_{2}$. Regardless of which state is achieved, both populations are in the end perfectly satisfied with their politicians because they share identical beliefs with the citizens and thereby promote language policies that are equilibrium policies from the perspective of all citizens.

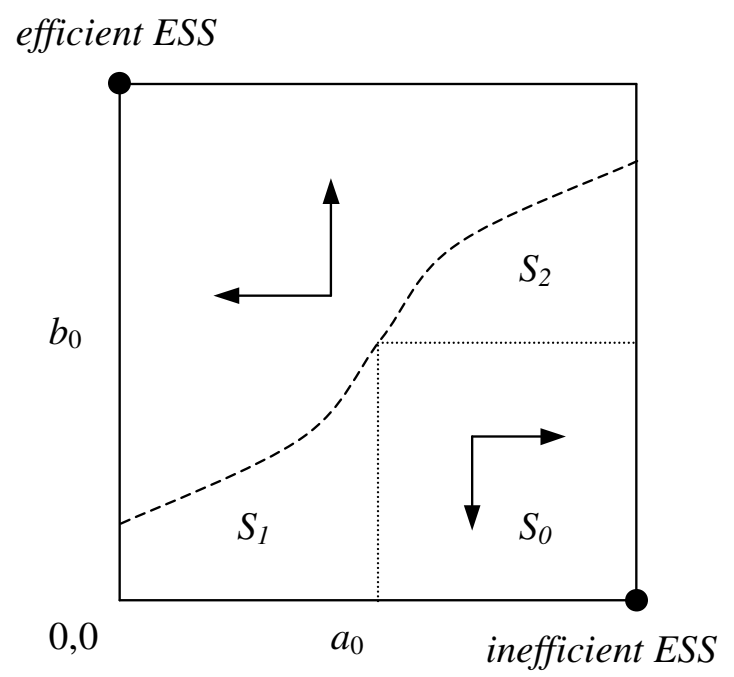

Fig. 2: Dynamics for political adjustment 
In other words, Figure 2 shows that in politics, initial majorities matter for learning; if population B is initially strong and population A is initially weak, a politically stable state induces the inefficient situation with trades in the inefficient language $\beta$. The result is independent on whether the politicians have superior coordinating abilities than citizens, or whether they are subject to more or less intensive public opinion pressure (frequency of elections). Learning in politics thus differs from learning in markets because in the latter case, the dynamics drives each population to the efficient stable state, with a exception of a degenerate initial distribution $\left(a_{0}, b_{0}\right)=(1,0)$. Unlike markets, politics is likely to deliver an inefficient outcome.

\section{Conclusion}

Although the dominant interest of Austrian School of Economics in markets with welldefined and well-protected property rights sways Austrian interest away from public choice, many Austrians dispose with a distinctive and common idea on how politics operates. One insight frequently mentioned in Austrian writings on the political economy is that voters systematically keep false or irrational beliefs. We regard Austrian hypotheses plausible, yet miss explicit theoretical foundations sustaining potential critique. In Sections 3 to 5, we found that Bayesian misperceptions are unlikely to sustain over time, behavioral anomalies make no difference between private and political choice, rational irrationality struggles with operational definition of meta-rationality and the implications of the consumption of pride goods or emotions do not exceed implications of classic rational ignorance.

We have offered an evolutionary model as an alternative, where collective play of an identical game led to a Pareto-inferior outcome than private play. The model addressed all modeling issues analyzed in Section 2.2: (i) deviations toward best responses are on the basis of opportunity costs, (ii) false beliefs play the crucial role throughout adjustment but disappear in stable states, (iii) citizen candidates are behaviorally identical to voters, (iv) information on updated aggregate beliefs is not available, so one tends to update private beliefs only on the basis of private experience, and (iv) comparative statics depends only on the initial distribution of population. This model shows that dispersed insights by Austrian economists can be extended if one engages in formal modeling of adaptive learning, and the evolution of strategies. 


\section{References}

Akerlof, George and William Dickens (1982) The Economic Consequences of Cognitive Dissonance, American Economic Review, 72, 307-19.

Alesina, Alberto and Allan Drazen (1991) Why Are Stabilizations Delayed, American Economic Review, 81, 1171-1188.

Alesina, Alberto and Roubini, Nouriel (1995) Political Cycles and the Macroeconomy, MIT Press.

Althaus, Scott (2003) Collective Preferences in Democratic Politics: Opinion Surveys and the Will of the People. Cambridge: Cambridge University Press.

Austen-Smith, David (1991) Rational Consumers and Irrational Voters, Economics \& Politics, 3 (1), 73-92.

Austin, D. Andrew, and Cox, Nathaniel T. (2007) Believing in Economic Theories: Sex, Lies, Evidence, Trust, and Ideology, Economic Inquiry, 45 (3), 502-518.

Besley, Timothy (2006). Principled Agents? The Political Economy of Good Government. Oxford: Oxford University Press.

Blankart, Charles B. and Koster, Gerrit B. (2006) Political Economics versus Public Choice: Two views of political economy in competition, Kyklos, 59 (2), 171-200.

Boettke, Peter and E. J. Lopez (2002) "Austrian Economics and Public Choice", Review of Austrian Economics, 15 (2-3), 111-119.

Boudreaux, Donald and Crampton, Eric (2003). Truth and Consequences: Some Economics of False Consciousness, Independent Review, 8 (1).

Brennan, Geoffrey and Hamlin, Alan (1998). Expressive voting and electoral equilibrium, Public Choice, 95 (1-2), 149-75.

Camerer, Colin (1995) Individual Decision Making. In Handbook of Experimental Economics. Eds. John Kagel and Alvin E. Roth. Princeton: Princeton University Press, 587703.

Caplan, Bryan (2000) "Rational Irrationality: A Framework for the Neoclassical-Behavioral Debate”, Eastern Economic Journal, 26, pp. 191-211.

Caplan, Bryan (2001a) "Rational Ignorance vs. Rational Irrationality", Kyklos, 54 (1), 3-26.

Caplan, Bryan (2001b) "What Makes People Think Like Economists? Evidence from the Survey of Americans and Economists on the Economy", Journal of Law and Economics, 44, 395-426.

Caplan, Bryan (2002) "Systematically Biased Beliefs about Economics: Robust Evidence of Judgmental Anomalies from the Survey of Americans and Economics on the Economy", Economic Journal, 112, 433-458.

Caplan, Bryan (2003) “The Logic of Collective Belief”, Rationality and Society, 15 (2), 21842.

Caplan, Bryan (2005a) "From Friedman to Wittman: The Transformation of Chicago Political Economy", Economic Journal Watch, 2 (1), 1-21.

Caplan, Bryan (2005b) "Rejoinder to Wittman: True Myths", Economic Journal Watch, 2 (2), 165-185. 
Caplan, Bryan and Edward Stringham (2005) "Mises, Bastiat, Public Opinion and Public Choice", Review of Political Economy, 17 (1), 75-109.

Caveiro, Antonio (2005) How to Classify a Government? Can a Neural Network Do It? University of Evora Working Paper 9/2005.

Gigerenzer, Gerd, Todd, Peter and ABC Group, eds. (1999) Simple heuristics that make us smart. Oxford: Oxford University Press.

Heinemann, Friedrich (2004) Explaining Blockades to Beneficial Policy Reforms - an Empirical Investigation, Applied Economics Quarterly, 55, 9-26.

Howitt, Peter and Ronald Windtrobe (1995) The Political Economy of Inaction, Journal of Public Economics, 56, 329-353.

Ikeda, Sanford (2003) How Compatible are Public Choice and Austrian Political Economy? The Review of Austrian Economics, 16 (1), 63-75.

Krishna, V., and J. Morgan (2001) A Model of Expertise, Quarterly Journal of Economics, $116,747-75$.

Lee, David S., Moretti, Enrico and Butler Matthew J. (2004) Do Voters Affect or Elect Policies? Evidence from the US House, Quarterly Journal of Economics, 119 (3), 807-859.

Martinelli, Cesar (2006) Would Rational Voters Acquire Costly Information? Journal of Economic Theory, 127 (1), 225-51.

Mill, James Stuart (1861/1972) Considerations on Representative Government, in H.B. Acton, ed., Utilitarism, on Liberty and Considerations on Representative Government, J.M. Dent \& Sons: London.

Mises, Ludwig (1979) Economic Policy: Thoughts for Today and Tomorrow. Regnery/Gateway, Chicago.

National Survey of Public Knowledge of Welfare Reform and the Federal Budget (1995). Kaiser Family Foundation and Harvard University.

Persson and Tabellini, (2000) Political Economics: Explaining Economic Policy, MIT Press.

Rabin, Matthew and Schrag, Joel L. (1999) First Impressions Matter: A Model of Confirmatory Bias, The Quarterly Journal of Economics, 114 (1), 37-82.

Romer, David (2003) Misconceptions and Political Outcomes, Economic Journal, 113, 1-20.

Rubin, Paul H. (2003) Folk Economics, Southern Economic Journal, 70(1), 157-171.

Skousen, Mark (2005) Vienna and Chicago: Friends or Foes? A Tale of Two Schools of FreeMarket Economics, Capital Press.

Survey of Americans and Economists on the Economy, 1996. The Washington Post, Kaiser Family Foundation and Harvard University.

Stigler, George (1971) The Theory of Economic Regulation, Bell Journal of Economics and Management Science, 2 (1), 3-21.

Wittman, Donald (1989) Why Democracies Produce Efficient Results, Journal of Political Economy, 97 (6), 1395-1424.

Wittman, Donald (1995) The Myth of Democratic Failure. Chicago: University of Chicago Press. 
Wittman, Donald (2005a) "Reply to Caplan: On the Methodology of Testing for Voter Irrationality", Economic Journal Watch, 2 (1), 22-31.

Wittman, Donald (2005b) "Second Reply to Caplan: The Power and the Glory of the Median Voter”, Economic Journal Watch, 2 (2), 186-195. 


\section{IES Working Paper Series}

2006

1. Martin Gregor: Globální, americké, panevropské a národní rankingy ekonomických pracovišt

2. Ondřej Schneider: Pension Reform in the Czech Republic: Not a Lost Case?

3. Ondřej Knot and Ondřej Vychodil: Czech Bankruptcy Procedures: Ex-Post Efficiency View

4. Adam Geršl: Development of formal and informal institutions in the Czech Republic and other new EU Member States before the EU entry: did the EU pressure have impact?

5. Jan Zápal: Relation between Cyclically Adjusted Budget Balance and Growth Accounting Method of Deriving 'Net fiscal Effort'

6. Roman Horváth: Mezinárodní migrace obyvatelstva v České republice: Role likviditních omezení

7. Michal Skořepa: Zpochybnění deskriptivnosti teorie očekávaného užitku

8. Adam Geršl: Political Pressure on Central Banks: The Case of the Czech National Bank

9. Luděk Rychetník: Čtyři mechanismy př́ijmové diferenciace

10. Jan Kodera, Karel Sladký, Miloslav Vošvrda: Neo-Keynesian and Neo-Classical Macroeconomic Models: Stability and Lyapunov Exponents

11. Petr Jakubík: Does Credit Risk Vary with Economic Cycles? The Case of Finland

12. Julie Chytilová, Natálie Reichlová: Systémy s mnoha rozhodujícími se jedinci v teoriích $F$. A. Hayeka a H. A. Simona

13. Jan Zápal, Ondřej Schneider: What Are Their Words Worth? Political Plans And Economic Pains Of Fiscal Consolidations In New Eu Member States

14. Jiří Hlaváček, Michal Hlaváček: Poptávková funkce na trhu s pojištěním: porovnání maximalizace paretovské pravděpodobnosti přežití steorií EUT von-Neumanna a Morgensterna a s prospektovou teorii Kahnemana a Tverského

15. Karel Janda, Martin Čajka: Státní podpora českého zemědělského úvěru v období pred vstupem do Evropské unie

16. Nauro F. Campos, Roman Horváth: Reform Redux: Measurement, Determinants and Reversals

17. Michal Skořepa: Three heuristics of search for a low price when initial information about the market is obsolete

18. Michal Bauer, Julie Chytilová: Opomijená heterogenita lidí aneb Proč afrika dlouhodobě neroste

19. Vít Bubák, Filip Žikeš: The Price of Stock Trades: Evidence from the Prague Stock Exchange

20. Vladimír Benáček, Jiří Podpiera a Ladislav Prokop: Command Economy after the Shocks of Opening up: The Factors of Adjustment and Specialisation in the Czech Trade

21. Lukáš Vácha, Miloslav Vošvrda: Wavelet Applications to Heterogeneous Agents Model

22. Lukáš Vácha, Miloslav Vošvrda: “Morální hazard“ a „neprýznivý výběr" při maximalizaci pravděpodobnosti ekonomického prězití

23. Michal Bauer, Julie Chytilová, Pavel Streblov: Effects of Education on Determinants of High Desired Fertility Evidence from Ugandan Villages

24. Karel Janda: Lender and Borrower as Principal and Agent

25. Karel Janda: Optimal Deterministic Debt Contracts

26. Jiří Hlaváček: Pojištění vkladů: současný stav, srovnání a perspektiva v kontextu EU

27. Pavel Körner: The determinants of corporate debt maturity structure: evidence from Czech firms

28. Jarko Fidrmuc, Roman Horváth: Credibility of Exchange Rate Policies in Selected EU New Members: Evidence from High Frequency Data 
29. Natálie Reichlová, Petr Švarc: Strategic Referring in Labor Market Social Networks

30. František Turnovec: Publication Portfolio of the Czech Economists and Problems of Rankings

31. Petr Kadeřábek : Correcting Predictive Models of Chaotic Reality

32. Wadim Strielkowski : People of the road: the role of ethnic origin in migration decisions. $A$ study of Slovak Roma asylum-seekers in the Czech Republic in 1998-2006

2007

1. Roman Horváth : Estimating Time-Varying Policy Neutral Rate in Real Time

2. Filip Žikeš : Dependence Structure and Portfolio Diversification on Central European Stock Markets

3. Martin Gregor : The Pros and Cons of Banking Socialism

4. František Turnovec: Dochází $k$ reálné diferenciaci ekonomických vysokoškolských vzdělávacích institucí na výzkumně zaměřené a výukově zaměřené?

5. Jan Ámos Víšek : The Instrumental Weighted Variables. Part I. Consistency

6. Jan Ámos Víšek : The Instrumental Weighted Variables. Part II. $\sqrt{n}$ - consistency

7. Jan Ámos Víšek : The Instrumental Weighted Variables. Part III. Asymptotic Representation

8. Adam Geršl : Foreign Banks, Foreign Lending and Cross-Border Contagion: Evidence from the BIS Data

9. Miloslav Vošvrda, Jan Kodera : Goodwin's Predator-Prey Model with Endogenous Technological Progress

10. Michal Bauer, Julie Chytilová : Does Education Matter in Patience Formation? Evidence from Ugandan Villages

11. Petr Jakubík : Credit Risk in the Czech Economy

12. Kamila Fialová : Minimální mzda: vývoj a ekonomické souvislosti v České republice

13. Martina Mysíková : Trh práce žen: Gender pay gap a jeho determinanty

14. Ondřej Schneider : The EU Budget Dispute - A Blessing in Disguise?

15. Jan Zápal: Cyclical Bias in Government Spending: Evidence from New EU Member Countries

16. Alexis Derviz : Modeling Electronic FX Brokerage as a Fast Order-Driven Market under Heterogeneous Private Values and Information

17. Martin Gregor : Rozpočtová pravidla a rozpočtový proces: teorie, empirie a realita České republiky

18. Radka Štiková : Modely politického cyklu a jejich testování na podmínkách ČR

19. Martin Gregor, Lenka Gregorová : Inefficient centralization of imperfect complements

20. Karel Janda : Instituce státní úvěrové podpory v České republice

All papers can be downloaded at: http://ies.fsv.cuni.cz

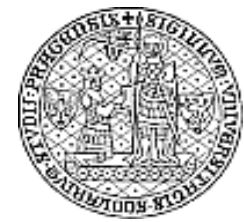

Univerzita Karlova v Praze, Fakulta sociálních věd

Institut ekonomických studií [UK FSV - IES] Praha 1, Opletalova 26

E-mail : ies@fsv.cuni.cz

http://ies.fsv.cuni.cz 